\title{
Poetry as Disruptive Pedagogy: Raising Therapists in the Faculty of Science
}

\author{
Paul Rhodes ${ }^{\mathrm{a}}$ \\ Corresponding author: Paul Rhodes (p.rhodes@sydney.edu.au) \\ aAssociate Professor, Clinical Psychology Unit, University of Sydney
}

Keywords: poetry, pedagogy, clinical psychology, poetics, introspection

\begin{abstract}
In this paper I invite further dialogue about the art of introspection in psychology, turning inwards, slowing down, and also contemplating how distress is situated in place and time. Poetry serves as both a form of inquiry and communication, one which can begin conversations with oneself and students beyond the technical demands of the profession of clinical psychology. It can help to position therapy, as both an interpersonal encounter and cultural artefact, rather than solely an expert-driven enterprise. My field, as a science needs interrupting by the humanities, by both phenomenology and politics. I will then demonstrate how I have used specific works of poetry as a pedagogical tool, to introduce my seminars and open the hearts of my students. Poetry offers a means by which students can be moved not only taught; to rediscover their own internal experience, to wonder about that of others, or engage in critical reflection rather than simple action. This paper is written loosely; semi-bricolage, and will include excerpts from a variety of works of poetry, including original pieces and a number of vignettes from the classroom and clinic.
\end{abstract}

\section{On bricolage}

Given that some scientists might be reading this paper I begin by explaining the way it has been written. A 'bricoleur' is a handyman, or jack of all trades who uses a variety of means to perform a task DIY, in this example, quotes, vignettes, poems, lists, doodles and a little didactic writing (Denzin \& Lincoln, 2000). My aim is not to provide a definitive argument, to punctuate or finalise, but rather to leave things open and messy.

\section{The rhetoric of clinical psychology}

A work of art is not transmitted or derived - it is a creative reorganization of those very conditions to which a causalistic psychology must always reduce it. The plant is not a mere product of the soil; it is a living, self-contained process which in essence has nothing to do with the character of the soil. (Jung, 2001, p. 990.)

Clinical psychology is a sub-field of psychotherapy, but positions itself as dominant rhetorical community (Miller, 1994), standing above psychotherapy, family therapy and counselling because of its affiliation with science, and a wider variety of schema.

Accountability to empirical evidence.

The primacy of the individual.

The privileging of rationality.

The othering of abnormality.

The instrumentalisation of distress. 
The mechanization of treatment.

The marginalization of the humanities, including philosophy, sociology and the arts.

Uni-disciplinarity.

Clinical psychology has its mythological origins in the Boulder Conference in 1945, when it was enshrined as a scientist-practitioner model of therapy, aligned with the medical model as an allied profession. Albee (1998) looks back on this period:

It is hard to overstate the naivety of the early clinical psychology graduate students (like me). Almost all were middle-class males, mostly ex-soldiers, airmen, and sailors, respectful of authority, accepting of what we were told, following orders, we embraced the psychiatric model because nothing else was presented to us. (p. 190)

Therapists must now follow the evidence when conducting treatment, and contribute to that research in an iterative cycle. Therapist competence is focused on technique:

not on the enlightenment of the person,

on prior analysis,

not made of flesh,

or being able to sit,

or a capacity for intersubjectivity,

or on a reckoning with privilege,

on activist-practice.

A recent paper by Waller (2009) exemplifies this rhetorical legacy. (I remember reading Skinner's Walden 2, written three years after Boulder, when I was a teenager). Waller coined the term Therapist Drift to mark the psychologist who deviates from the Cognitive Behaviour Therapy (see Figure 1), into other less established models, including schema therapy or mindfulness. He coins this a drift from 'doing' to 'talking' therapies and warns that we must not "behave in ways that reflect our own twisted thinking (p. 122)." No dialogue, only action.

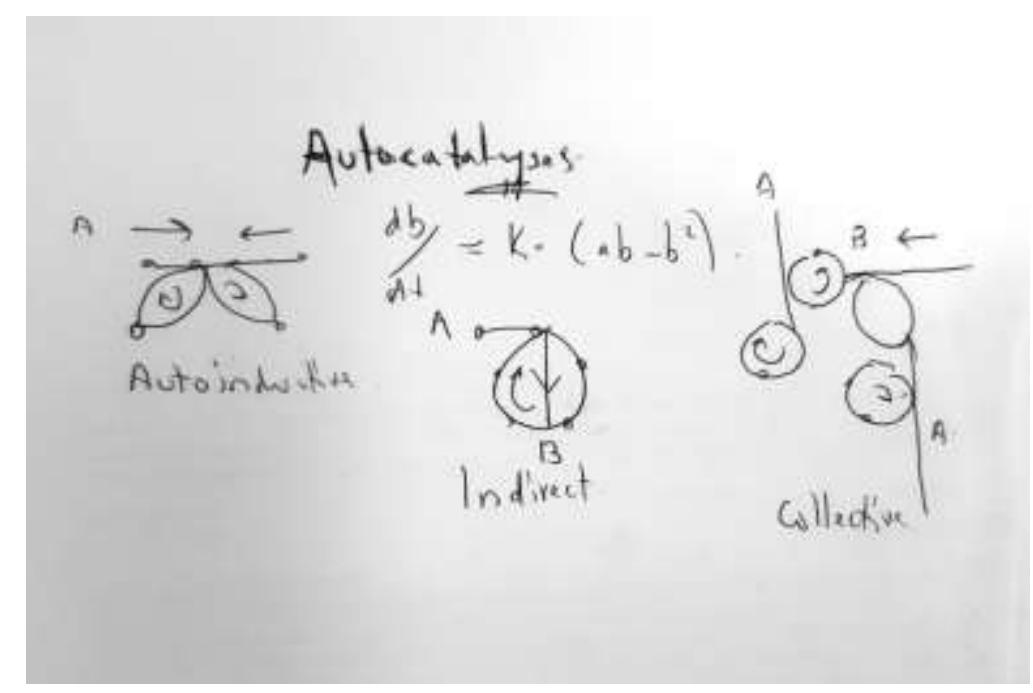

Figure 1: Image from a doodle by author, inspired by Plasson, Brandenburg, Jullien et al. as an example of information-processing $(2011$, p. 1.) 
"What is love except another name for the use of positive reinforcement? Or vice versa." (Skinner, 1948, p.282)

The kind of professional surveillance demonstrated by Waller is the product of an exclusive adherence to evidence-based practice, cutting us off from other forms of knowledge that cannot be found in scientific journals, especially those forms that exist within ourselves, our bodies and beyond.

Klempe and Valsiner (2014) assert that psychology is "guilty of crimes against humanism in the building of a science, and that it has been involved in that crime over the last two centuries" (p. ix). Is there a risk that clinical psychologists, taught to focus mainly on technique, are at risk of losing touch with themselves as they prepare for a career as therapists? The dialogic world is made up of both vertical (intrapsychic) and horizontal (interpersonal) voices, all involved in the therapeutic polyphony. Must we silence these voices to stop the drift?

Our own research into the narratives of therapists lives (Salter \& Rhodes, 2018) found that many clinical trainees come to rediscover themselves in the years following training; realigning techniques with their values, rediscovering their emotions and finding greater genuineness. I write about my own loss of interiority, here.

\section{Memory}

I remember when I worked at the Children's Hospital at Westmead, I used to sit down for thirty minutes and make a plan for every session, drawing decision trees and diagrams.

I would hypothesise.

I sat on a green chair outside of my room during the session.

The disembodied therapist.

I remember a few years before that smashing my car on the way to a domestic violence case in the suburbs, scraping the side door, with my diagrams, and being told I was a misogynist because I double parked and I wore a thick woven sweater.

I remember I had another client who I did better with but messed up some important facts and got fired.

And a man who I hurt badly because of object relations psychotherapy.

I remember when I kicked myself out of the supervision group and then years later reappeared by mistake and was told it was because I knew where I belonged.

And getting fined in the tunnel for speeding, one point left, because I was so nervous.

Introspection, however, need not simply be a personal process, focused on self-understanding or self-compassion, but can serve a more critical function (Gemignani, 2016); the interpretation of the personal in the light of socio-cultural context. Clinical psychology can also be questioned for this kind of blindness, as it operates with little cultural awareness. The cognitive-behaviour 
therapy from which IT MUST NOT DRIFT is a product of the information-processing 1980's; a product of the times, where the formulation of human suffering is drawn up in cybernetic diagrams (Figure 1). It is also one step in a long history of rational stoicism, dating back to Greek and Roman philosophy, well forgotten by most therapists (Robertson, 2010). Clinical psychology, in failing to understand the society that surrounds it, is at risk of healing the sick with their own malady. At the moment we are channelling much of our research and resources into the use of artificial intelligence through e-therapy, as a possible (cost-efficient) answer to human distress (Fairburn \& Patel, 2014). Optimal efficiency. Machine learning. Our solution to the anxiety and depression of the increasingly isolated individual is our Promethean Shame.

We eliminate the therapist all together.

...we can only conceive of the human as a construction, especially a faulty one, when we adopt the perspective of the machine. Only if this category is accepted as being both universally applicable and exhaustive can such a reinterpretation take place and can the unconstructed appear as the badly constructed. (Anders 1987, p. 32, trans. Hausekeller, 2013)

So-called 'mental illness' can be positioned as a socio-cultural phenomenon. Anderson (2009) coins the phrase 'affective atmosphere;' as if the emotions of individuals can coalesce, like smoke, in their own streets, suburbs and cities, leaking out every now and then to comprise culture. Externalised, prowling, these forces can infect the individual, creating disorders that once reified cannot see their creator.

\section{Case vignette}

1. Cary is a 16 year old girl who lives on one of the richest streets in Sydney, she can see the water from her bedroom window and wears an old fashion straw hat to School. She studies very hard and always pleases her parents with her high marks and attitude. (DSM5: Compulsive Compliance 54.62 made up disorder).

2. $22 \mathrm{kms}$ away is a small pub in the City, the home of the Push, where leading thinkers and feminists, including Germaine Greer took on Sydney....it is like this never happened.

3. "The Royal George was the headquarters of the Downtown Push, usually known as just the Push.... As well as the Libertarians and the aesthetes there were the small-time gamblers, traditional jazz fans and the homosexual radio repair men who had science fiction as a religion. The back room had tables and chairs. If you stuck your head through the door of the back room you came face to face with the Push. The noise, the smoke and the heterogeneity of physiognomy were too much to take in. It looked like a cartoon on which Hogarth, Daumier and George Grosz had all worked simultaneously, fighting for supremacy." (Clive James, 1981, p140.)

4. Cary wants to be School Captain more than life itself and for the first time in her life was unable to meet her expectations of herself and failed. You can't hear her cries and she is admitted, makes her own protest and doesn't get up the next morning. They walk the dog at breakfast as if history repeats.

5. “Women's identities were forged in social conditions that imposed restrictions on their ability to achieve subjectivity. During periods of liminality, the women undergo a process of detachment from an earlier fixed point. These periods of betweenness are accompanied 
by symbolic behaviors, such as dietary control, abjection, or suicidality/self-harm, or the object of medical attention. The liminal persona is characterized by their emotional, physical, or intrapsychic states, as they transition into a new state that is defined by name and cultural symbols the anorexic."(Malecki \& Rhodes, 2018, p. 240)

\section{Poetry in the classroom}

bell hooks (1994) argues for an 'engaged pedagogy', not just PowerPoint, meta-analysis and facts, but built on an encounter between teacher and student, jointly in dialogue as whole people, bodies, questioning, resisting. How might we teach students to remember they are present in the therapy room, filled with their own voices and surrounded by affective atmospheres? How can we start them on a journey towards greater self/cultural awareness?

De Cossen (2002) comments that "For many ... teachers and students their ... self is often neglected, hidden, even repressed to conform to the 'norm' that is teacher student" (p. 11).

It is not just the self, however, that must be allowed into the classroom, invited/permitted to enter, welcomed, but a critical self that can question the paradigms of clinical psychology. Reflective practice is well established as a process that supports the efficacy of the psychologist in training (Burgess, Rhodes, \& Wilson, 2013), allowing therapists to first about their own internal responses as therapists in retrospect and later in situ. The classroom, however, must also be a place where students are able to question to the post-positivist paradigms behind the evidence for clinical psychology and its status as a disembodied technology. The arts serve as one of many epistemological tools for this purpose (MacKenzie, 2013), introducing news of difference into the science-practice cycle. As she puts it,

...poetry engages the body/mind/soul in an aesthetic, intellectual response that allows students the opportunity to enter into the ambiguous space of (un)knowing and (dis)connection, creating relationship that is both undefined and transitional. It is within the ambiguity of this space that one finds herself grasping for some sense of self and experience-searching for meaning (p. 12).

Poetry allows for the training of the heart, not just the mind (Rappaport, 2006). Following are 3 scenes from the classroom, each using poetry for these purposes. In the first one the poem 'Southerly' (Rhodes, 2018) was used at the beginning of a Reflective Practice Seminar to open up students to the everyday lived experience of being a therapist/to show how the psychologist suffers alongside the client. In the second (my) poem 'Exposure' was used to try and demonstrate the human experience of recovery during a seminar that focused on teaching a more behavioural manualized treatment for anorexia nervosa. In the third the poem "Grief for Hire" (Blayney, 2018) was used as a radical act of defiance against the contemporary mental health system, to prepare students for a seminar on the recovery movement.

\section{Scene 1: Reflective practice November, 2018}

The poem below was read out by the author at the beginning of a three lecture series on reflective practice for trainee clinical psychologists. The lectures focused on teaching the students different models of reflective practice, applying these models to case material and conducting role play exercises. The series, however, started with is poem, with the aim of sensitising students to their own internal life, giving them permission to turn inwards and remember that they too are sitting in the therapy room as living bodies. I wrote this poem for the series We Are Barometers of the City: Collected Poems by Psychologists (Rhodes, Azim, Saab, et al. 2018). Once the poem was read students were asked for their reflections. 


\section{Southerly}

I am a barometer of the City. Not the whole city, but the lives that flow along the bus and train routes and roads from the suburbs to my office, along the streets, from the station, near the Coke sign, past the café and the Mexican, down the hill. From the beaches, the businesses and the red brick. A river, where all roads lead to my poor self, to the oasis and quiet of my room, where I try and breath. I have to purposefully breathe so I don't say anything. I have to trust and wait.

Young children, some pretending everything is fine, some heavy with the burden of their parents, some broken, others much worse, cutting themselves, fascinated with broken glass, hidden. Some waiting for justice. And a woman who told me she has five spirits inside of her and that one was dead.

I am a barometer of my City. Not the whole city, but the weather that I see as I look out of my window across the rooftops below the inpatient unit where young people stay. It's like a hotel up there. I felt the ground shake the other day and thought there was an earthquake, but I still had to carry on. I put my arm around my colleague and told her she was good and she did too. We are as lonely as our patients in this factory in the City.

Cocaine is popular, and self-harm, suicide, starvation. Perfectionism. Violence. Couples drift and argue, and they struggle to answer my questions about how they met, and what first attracted them to each other and when they knew he/she was the one. Everything is the other persons' fault. I try every trick I have. I am a barometer of the City.

Imagine what it would be like to spend your day trying to keep a loved one alive. A mother or a father, a wife or a husband, trying to keep their loved one alive. They watch the stairs and balconies, the drawers and the drains and the doorways. Sometimes they resign themselves and accept that it is just going to happen. Imagine what it would be like to know less about yourself and how you feel than a doorpost, to live disembodied, with no-one home, walking around the City every day without your body. You watch the stairs and the balconies, the drawers and the drains, and the doorways.

I stop for a coffee every morning before clinic just to feel I belong and the owner tells "You got this."

I stop for coffee every morning just to feel like I belong and they call me "Pauly."

Every Thursday they have a pasta of the week. There is an old man with a dog that scratches his back on the pavement. Every week they give him free pasta and the man buys fresh mincemeat and feeds it to the dog with his fingers.

The City is a character in their lives and my own. "Dufrenne helps us think of atmospheres in terms of singular affective qualities that express a certain world" (Anderson, 2009, p.3.). At 
night when everybody is asleep the city roams the suburbs, growling, devouring souls.

During the day it lives in the private schools who drive their kids to death and in the poor schools where the boys dance to the death in the playground. It lives in the office blocks and the Mosques, up in the Mountains and out West.

Like a barometer though I have to wait. I have to make myself breathe, to sit still. I have to wait. I ask questions and they answer but we all wait, the mums and dads and the kids. We wait.

"Tell me what has brought you here today?" "What effect do you think he would say that has had on him?" "I can see you're distressed, what has happened?" "How close would you say they are?" "Who is the first person you would turn to"? "What message do you think she was trying to send"?

In the polyphony we wait.

I remember once nearly drowning in the ocean trying to swim from point to point and the waves were too big. I put my hand in the air so a fisherman could see me but what could he do. I felt the pull of the sea and the feeling that I should give in to it. But in the end I took a wave onto the rocks and clambered up all bloody but free. It is this wave that we wait for. We wait, together.

I remember once getting lost in the bush and trying to track back on routes I had used before and then getting scared and seeing ghosts and couldn't get out. It was hot and turning dark. And then a car full of young men came by with beers in the back of their truck and took me home. It is these men that we wait for, together.

Permission for reproduction granted by Editor, Human Arenas (Rhodes, 2018).

\section{Scene 2: Family-based treatment for anorexia nervosa, July 2018.}

I read the poem below at the start of a lecture within a series on family therapy, this one focused on the Maudsley model of family based treatment for anorexia nervosa. The model has reasonable efficacy in the literature, in manualized, but critics argue that it doesn't cater for the voice of the young person and is too exclusively behavioural. I started with this poem, an original, written about the life of one of my own clients, now recovered. The aim was to ensure that students saw beyond the treatment model, to gain some access to what it might be to suffer and recover from anorexia nervosa. Students were asked for their reflections after the poem was read. 


\section{Exposure}

In a dark street she was cut deep

And fell asleep/

For fifteen years

Appearing here and there

In front of an old tree

At the traffic lights

In the school library

Waking at night-strike

The assholes of the world tried

All fingers and thumbs

Her response was frozen.

Alexithymic.

Pre-narrative highlights

Bright knives

This shy girl

Remembers the emergency room lights.

Losing her appetite

Nothing to say in the crisis

....And bell hooks rings for the disappeared

Now she has tattoo

Of a biological heart on her arm

As she serves coffee in Glebe

Kisses her boyfriend in the street

Wears her dress to dinner for the first time like a Queen

Training to be nurse,

Healing the sick for a living and liking it

Her parents look back 
Proud of meal-time battles

Shower supervision and snacks

From bradycardia, to white hair and hypothermia

United when it mattered

Today she smiled at me in black jeans

Merleau Ponty's mindbody

Tracing hiccups and trajectories

Bearing witness to recovery

Scene 3: Community-based approaches to 'mental health', November, 2018.

First of a three-part seminar. This one focused on what peer-workers can offer to the recovery of those experiencing severe emotional distress. The seminar included a review of literature, role play demonstrations, and interviews with peer workers. We started with a poem by peer worker, educator, poet-extraordinaire Alise Blayney (2018).

\section{Grief for Hire}

I AM grieffor hire, a Poetess — not PTSDs marauded Duchess, nor the Black Dog's mistress. I used to be the clinical Countess of Distress!

I HAVE a broken aorta, when under hypnosis ticks with postmodern tacky-cardia.

I HEAR absinthe's green fairy whirlpool crash like car smash glass into community houso's observation hole.

I SEE invisible cloaked entities dressed as spiritual emergencies, infecting those whose senses are not anaesthetised. They incubi and succubi my white hospital gown like a djinn and tonic lullaby.

I WOULD drop vowels for Rhett Butler, do post traumatic time behind the fishbowl for Scarlett O'Hara.

I WANT soft asylum, 33 inch vinyl and spinning Roy Orbison.

I AM Rimbaud's THIEF of FIRE, a Poetess. Not PTSDs marauded Duchess, nor the Black Dog's mistress. I used to be the clinical Countess of Distress.

I PRETEND that 9 years ago, I wasn't a sensory deprived TANKED mess.

I FEEL ambidextrous with the crookedness, and RAGE over the cuckoo clock's rooftops.

I TELL Blake his RINTRAH has gone too far — knockout pills and acute amnesia wrack with wrath, a reprobate wrecking ball. 
I TOUCH marriage of perception through chemical incarceration and sink into delirium the quack tells me I look like the spokesperson for vandalism!

I WORRY that the rough of the dialogue does your head in and that the curse of the coarse is coercion of sin.

I CRY because Mr Disney never told me the looking glass felt so like sheer fucking fear.

I SMILE when you spit delirious 'the road of HER excess leads you to the palace of resilience.'

I AM the serrated jaw of Dante's grand larceny circle. I lurk between the 5th of anger, the 7 th of murder.

I UNDERSTAND when God gives you a gift, the angel of shibboleth gives you a whip.

I SAY drink the sweet elixir and watch your syntax sizzle off my rapid cycling tongue, to a beat that just belts on and on and on.

I DREAM of astral travel and meeting you in the ether, lucid and tender, where

I TRY to exalt this zyprexa stupor into the stars / release my pressure points into the ooh la la stars.

I HOPE to enter your white wonderland chamber, but your syntactical activist tongue SHIPWRECKS my lips, until I'm trembling and sick.

I LOVE that you said poetry is both confession and exorcism - so we should Houdini out of the syntax straight jacket by sticking it to big pharma!

I am GRIEF FOR HIRE. Tell seclusion and restraint I want ceasefire.

Permission granted for reproduction from Editor, VerityLa. (Blayney, 2018).

\section{Poetics in the therapy room}

I read the word 'poetics' in a paper a few years ago (Seikkula \& Olsen, 2004), to describe what happens in the therapy room when everyone is Present and there is dialogue. When things slow down. When we watch and wait. When we hear a pin drop. When I can hear my own breath. When uncertainty is tolerated and something happens between people. When voices might be heard. When we allow a visitor into the room who no-one can see. There is a beauty to this process, rare when it happens, that goes beyond teaching skills, beyond therapy, where healing might be possible. The room can feel like a funeral, quiet, silent/ or like a celebration, respectful, with new air breathing in. When we get out of the way we see the human soul and system has its own way of healing, like a broken arm. Listen. Poetics are hermeneutic, meaning the participants are engaged in a process of decoding meaning, from behaviour, in ways that cannot be predicted. This is opposed to the rhetorical, where the therapist drives change. This is an ancient differentiation, Aristotelian, between creation and persuasion. 


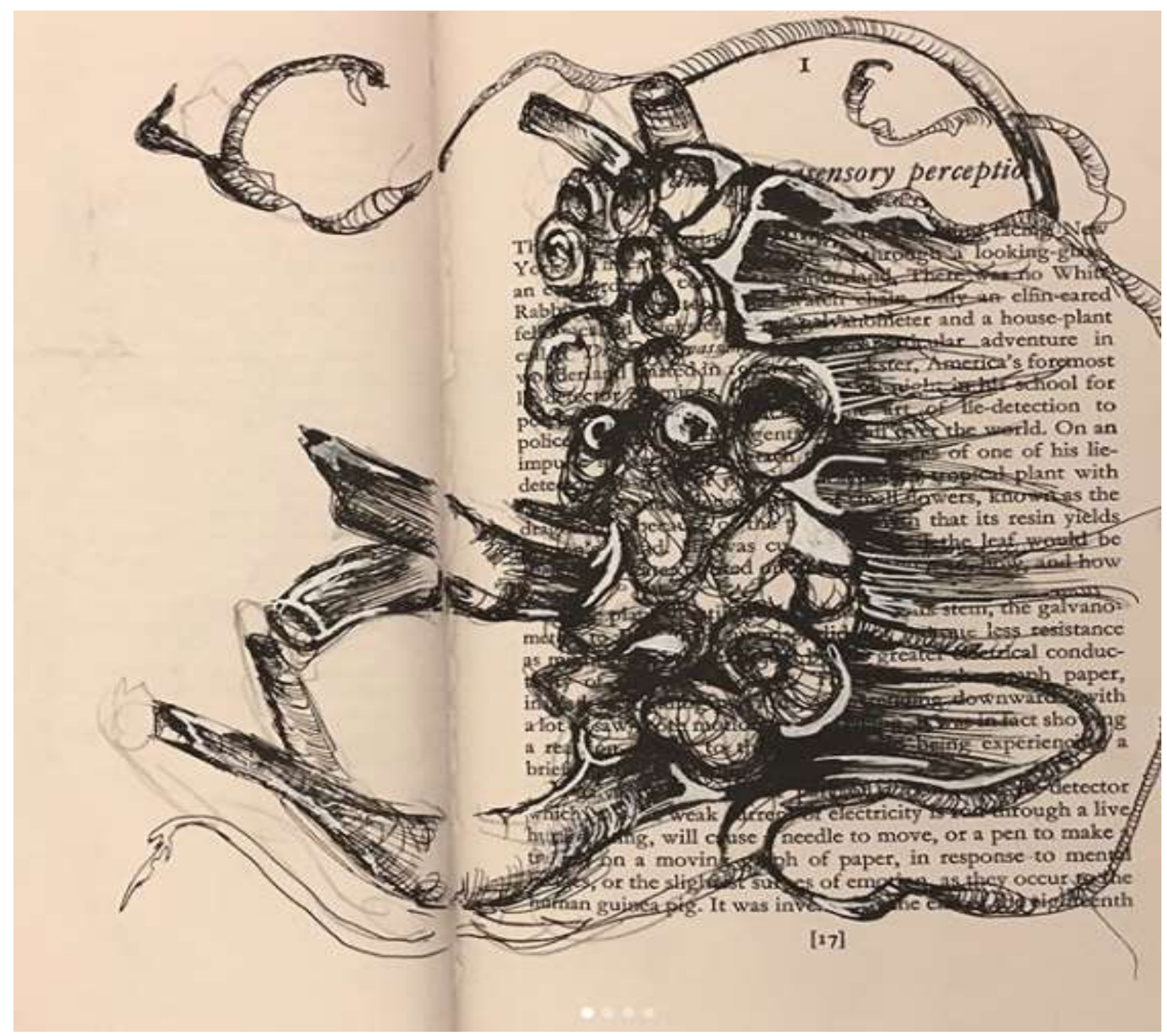

Figure 2: Sketches 2 by Sophie Rhodes 2018.

Poetics in the therapy room reveal the hidden meanings of behaviour, often the opposite of what it seems, paradoxical, self-contradictory. The double bind cannot be broken without a poetic key. (A young man, helpless, distressed, pushes everyone away from himself in attempt to draw them close). (A young woman, screams at her mother that she hates her, but is afraid she might never come back). (A middle aged couple distance and pursue but they have a secret contract to avoid). (A young girl, compulsively compliant, people-pleasing anger). (An eight year old child obsessed with knives but carries his own wounds).

Poetry in the classroom might serve as an introduction to poetics in the therapy room. 


\section{Acknowledgements}

I'd like to thank poet and educator, Alise Blayney for allowing me to publish her work, and for mentoring me in mine. Plus the journal Verity La. for allowing same.

\section{References}

Albee, G. W. (1998). Fifty years of clinical psychology: Selling our soul to the devil. Applied and Preventive Psychology, 7, 189-194. http://dx.doi.org/10.1016/S0962-1849(05)80021-6

Anders, G. (1987). Interviewt von M. Greffrath. In E. Schubert (Hrsg.), Günther Anders antwortet. Interviews \& Erklärungen. Mit einer Einleitung von Hans-Martin Lohmann. Tiamat, Berlin, 1987

Anderson, B. (2009). Affective atmospheres. Emotion, Space and Society, 2(2), 77-81.

Blayney, A. (2018). Grief for hire. In N. Featherstone, M. Seminara \& R. Coburn, (Eds.), The Hunger. Sydney: Verity La.

Burgess, S., Rhodes, O., \& Wilson, V. (2013). Exploring the in-session reflective capacity of clinical psychology trainees: An interpersonal process recall study. Clinical Psychologist. 17(3), 122-130.

Denzin, N., \& Lincoln, Y. (2000). Handbook of qualitative research (2nd ed.). Thousand Oaks, CA: Sage

de Cosson, Alex. (2002). The hermeneutic dialogic: Finding patterns amid the aporia of the artist/researcher/teacher. The Alberta Journal of Educational Research, xlviii (3), article on CD-ROM insert.

Fairburn, C. G., \& Patel, V. (2014). The global dissemination of psychological treatments: A road map for research and practice. The American Journal of Psychiatry, 171(5), 495498.http://dx.doi.org/10.1176/appi.ajp.2013.13111546

Gemignani, M. (2016). Toward a critical reflexivity in qualitative inquiry: Relational and posthumanist reflections on realism, researcher's centrality, and representationalism in reflexivity. Qualitative Psychology, 4(2), 185. http://dx.doi.org/10.1037/ qup0000070

Hausekeller, M. (2013, September, 13). Günther Anders on Promethean Shame (Part 1) [Blog post]. Retrieved from: http://hauskeller.blogspot.com/2013/09/gunther-anders-on-promethean-shame-part.html.

Hooks, Bell (1994). Teaching to trangress: Education and the practice of freedom. NY: Routledge.

Klempe, S., \& Valsiner, J. (2014). History and theory of psychology. Kierkegaard and the rise of modern psychology. USA: Piscatawny.

James, C. (1981).Unreliable Memoirs, Picador Books, p. 140.

Jung, C., (2001). On the relation of analytical psychology to poetry. In V. Leitch, W. Cain, L. Finke \& B. Johns (Eds.), The Norton anthology of theory and criticism (p. 990). London: W. W. Norton \& Company.

MacKenzie, S. (2013). Poetic praxis: Engaging body, mind, and soul in the social foundations classroom. Journal for Learning and the Arts. 9(1), 1-24.

Miller, C. (1994). Rhetorical community: The cultural basis of genre. In A. Freedman \& P. Medway (Eds.), Genre and the new rhetoric (pp. 67-78). London: Taylor \& Francis.

Plasson, R., Brandenburg, A., Jullien, L., \& Bersini, H. (2011). Autocatalyses. The Journal of Physical Chemistry, 115(28), 8073-8085.

Rappaport, M. (2006, September 5). The poetry of practice. Medical students voice the inexpressible through poetry. International Journal of Creative Arts in Interdisciplinary Practice Commentary. Retrieved from http://www.ijcaip.com/archives/IJCAIP-8-Rappaport.html

Rhodes, P. (2018). Southerly. In P. Rhodes, K. Azim, K. Saab, R. Nelson, J. River, L. Parker, C. MacAulay, A. Donnet, J. Breckenridge, D. Gessler, M. M. Salter, C. Langtiw, T. Rogers, T. \& A. Cook. (2018). We are barometers of the city: Collected poems by psychologists. Human Arenas, pp. 1-16.

Robertson, D. (2010). The philosophy of cognitive-behavioural therapy (CBT): Stoic philosophy as rational and cognitive psychotherapy. London: Karnac Books Ltd.

Salter, M., \& Rhodes, P. (2018). On becoming a therapist: A narrative inquiry of personal-professional development and the training of clinical psychologists. Australian Psychologist, 53(2018) 486-492. https://doi.org/10.1111/ap.12344

Seikjkula, J., \& Olsen, M. (2004). The open dialogue approach to acute psychosis: Its poetics and micropolitics. Family Process, 42(3), 403-422. https://doi.org/10.1111/j.1545-5300.2003.00403.x

Skinner, B.F. (1948). Walden two. Indianapolis: Hackett Publishing Company.

Waller, G. (2009). Evidence-based treatment and therapist drift. Behaviour Research and Therapy, 47, 119-127. https://doi.org/10.1016/j.brat.2008.10.018 